\title{
Response of Dry Bean Genotypes to Fusarium Root Rot, Caused by Fusarium solani f. sp. phaseoli, Under Field and Controlled Conditions
}

\author{
V. N. Bilgi, C. A. Bradley, and S. D. Khot, Department of Plant Pathology, K. F. Grafton, Department of Plant Sci- \\ ences, and J. B. Rasmussen, Department of Plant Pathology, North Dakota State University, Fargo 58105
}

\begin{abstract}
Bilgi, V. N., Bradley, C. A., Khot, S. D., Grafton, K. F., and Rasmussen, J. B. 2008. Response of dry bean genotypes to Fusarium root rot, caused by Fusarium solani f. sp. phaseoli, under field and controlled conditions. Plant Dis. 92:1197-1200.

Fusarium root rot of dry bean (Phaseolus vulgaris), caused by Fusarium solani f. sp. phaseoli, is a major yield-limiting disease in North Dakota and Minnesota. Although a few sources of partial resistance are available, most commercial cultivars grown in this region are susceptible, especially in the red kidney bean market class. This study evaluated three methods of screening for resistance to Fusarium root rot. A sand-cornmeal inoculum layer method, spore suspension method, and paper towel method were used to evaluate 11 dry bean genotypes for resistance to Fusarium root rot under growth-chamber conditions. These same genotypes were also evaluated in field trials at Fargo, ND, and Park Rapids and Perham, MN, in 2005. In all trials, the small red genotype VAX 3 was found to have a consistently high level of resistance to Fusarium root rot and could be used as a source of resistance by dry bean breeders. Correlation analyses between field and growth-chamber root rot ratings indicated that all three growth-chamber methods had significantly $(P \leq 0.05)$ positive correlations with field results from Perham and Fargo, which suggests that all three methods could be used to screen germplasm efficiently for resistance to Fusarium root rot.
\end{abstract}

Additional keywords: black bean, dark red kidney bean, great northern bean, navy bean, pinto bean, small red bean

The dry bean (Phaseolus vulgaris L.) production region in North Dakota and Minnesota produces more dry beans than any other area in the United States. Within this region, a number of different market classes are produced, including black, great northern, red kidney, navy, and pinto. Fusarium root rot, caused by Fusarium solani (Mart.) Sacc. f. sp. phaseoli W.C. Snyder \& H.N. Hansen, has been considered as one of the major yield-limiting diseases of dry bean in this region $(4,10)$.

Although a few sources of partial resistance are available $(1,3,5,6,9)$, most commercial cultivars grown in North Dakota and Minnesota are susceptible to $F$. solani f. sp. phaseoli. Cultivars in the red kidney bean market class have been observed as suffering more losses due to $F$. solani f. sp. phaseoli than some of the other market classes grown in the region (4). In general, cultivars developed from the large-seeded Andean gene pool such as red kidney bean

Corresponding author: C. A. Bradley

E-mail: carlbrad@uiuc.edu

Current address of C. A. Bradley: Department of Crop Sciences, University of Illinois, 1102 S. Goodwin Ave., Urbana 61801

Accepted for publication 17 April 2008.

doi:10.1094/PDIS-92-8-1197

(C) 2008 The American Phytopathological Society tend to be more susceptible to Fusarium root rot than those developed from the small-seeded Mesoamerican gene pool, such as black bean (1).

Many different screening methods have been used under controlled conditions to identify sources of resistance to $F$. solani $\mathrm{f}$. sp. phaseoli; however, most of these methods have not been compared with field tests using the same bean genotypes. Schneider and Kelly (13) evaluated a single greenhouse spore suspension screening method and compared it with field results; they demonstrated that this method was able to differentiate among bean genotypes and was significantly correlated with the results of field trials.

The objectives of this research were to (i) evaluate a set of dry bean genotypes in different market classes for resistance to $F$. solani $\mathrm{f}$. sp. phaseoli under field and controlled conditions and (ii) identify an efficient screening method that will help predict the reaction of a genotype to Fusarium root rot in the field.

\section{MATERIALS AND METHODS}

Dry bean genotypes. The genotypes Montcalm, Red Hawk, VAX 3, Rojo Chiquito, Othello, Maverick, Matterhorn, Eclipse, T-39, Norstar, and Vista were used in all trials conducted under field and controlled conditions (Table 1). Montcalm and Red Hawk are dark red kidney bean, VAX 3 and Rojo Chiquito are small red bean,
Othello and Maverick are pinto bean, Matterhorn is a great northern bean, Eclipse and T-39 are black bean, and Norstar and Vista are navy bean genotypes.

Disease evaluation. In all trials, roots were washed with water and root rot severity was rated using a 1-to-7 scale described by Schneider and Kelly (13), where $1=$ healthy roots with no discoloration of root or hypocotyl and no reduction in root mass; $2=0.1$ - to $0.2-\mathrm{cm}$ small reddish brown lesions at the base of the hypocotyl, with normal root mass and size; $3=$ increase in intensity and size and coalescing of localized root/hypocotyl lesions approximately $180^{\circ}$ around the stem, with lesions from 0.5 to $1 \mathrm{~cm}$ and 10 to $20 \%$ root discoloration but no reduction in root mass size; 4 = increase in intensity of discoloration and size of hypocotyl lesions, with lesions extending and completely encircling the stem, 5 to $10 \%$ root mass reduction, and $95 \%$ of the roots discolored; $5=$ increasingly discolored and extended hypocotyl lesions, with $100 \%$ of the roots intensely reddish-brown and 20 to $50 \%$ root mass reduction; $6=$ hypocotyl lesions encircling the stem extending up to $2 \mathrm{~cm}$, intense root mass discoloration, and 50 to $80 \%$ root mass reduction; and $7=$ pithy or hollow hypocotyl with very extended lesions, 80 to $100 \%$ root mass reduction, and functionally dead.

Sand-cornmeal inoculum layer method. A slightly modified version of a sandcornmeal inoculum layer method used previously to perform pathogenicity evaluations of Fusarium isolates on roots of wheat (Triticum aestivum L.) seedlings (15) was used to evaluate the effect of $F$. solani f. sp. phaseoli on the dry bean genotypes listed above. An isolate of $F$. solani $\mathrm{f}$. sp. phaseoli originally obtained from a dry

Table 1. Dry bean genotypes used in the Fusarium root rot studies and their corresponding market classes

\begin{tabular}{ll}
\hline Genotype & \multicolumn{1}{c}{ Market class } \\
\hline Eclipse & Black bean \\
Matterhorn & Great northern bean \\
Maverick & Pinto bean \\
Montcalm & Dark red kidney bean \\
Norstar & Navy bean \\
Othello & Pinto bean \\
Red Hawk & Dark red kidney bean \\
Rojo Chiquito & Small red bean \\
T-39 & Black bean \\
VAX 3 & Small red bean \\
Vista & Navy bean \\
\hline
\end{tabular}


bean field near Staples, MN was allowed to sporulate on half-strength potato dextrose agar (HSPDA; Becton Dickinson and Company, Sparks, MD) for 10 days under light and dark cycles of $12 \mathrm{~h}$ each at $23^{\circ} \mathrm{C}$. This isolate was chosen to be used in the trials due to its high level of aggressiveness on dry bean as observed in a preliminary trial with other $F$. solani $\mathrm{f}$. sp. phaseoli isolates (2). Eight 5-mm plugs of the culture were placed in $125-\mathrm{ml}$ conical flasks containing a presterilized sandcornmeal mixture (45 $\mathrm{g}$ of regular play sand, $5 \mathrm{~g}$ of cornmeal, and $10 \mathrm{ml}$ of distilled water). Flasks were kept at room temperature for 7 days and were shaken daily by hand to allow the fungus to grow throughout the contents of the flask. In 266-ml plastic drinking cups with small holes at the base for water drainage, $15 \mathrm{~g}$ of premium grade coarse dry vermiculite was added and compressed, followed by a 15-g equal layer of inoculum which was then covered with $8 \mathrm{~g}$ of vermiculite. Two seeds of a genotype were placed on the vermiculite layer followed by another $8-\mathrm{g}$ layer of vermiculite to cover the seeds. Three cups of each genotype were placed in trays and kept in growth chambers where they were watered daily. A cycle of $14 \mathrm{~h}$ of light and $10 \mathrm{~h}$ of darkness, with day and night temperatures of 21 and $18^{\circ} \mathrm{C}$, respectively, was maintained in the growth chamber. Root rot severity was evaluated 18 days after planting. The statistical design was a randomized complete block (RCB) with three replications. The experiment was repeated once.

Spore suspension method. A spore suspension inoculation method similar to those described by Schneider and Kelly (13) and Mondal et al. (12) was used to evaluate the response of dry bean genotypes to $F$. solani f. sp. phaseoli. Cultures of $F$. solani f. sp. phaseoli on HSPDA were allowed to sporulate for 10 days under light and dark cycles of $12 \mathrm{~h}$ each. Two seeds of a dry bean genotype were planted in 50-ml conical-bottom polypropylene centrifuge tubes $(29 \mathrm{~mm}$ in diameter by $115 \mathrm{~mm}$ in length; VWR International, West Chester, PA) filled with vermiculite and topped with a thin layer of play sand. After 10 days, $10 \mathrm{ml}$ of a suspension of $5 \times$ $10^{4}$ macroconidia/ml were pipetted onto the surface of the sand layer. Three tubes of each genotype were placed in test tube racks and kept in a growth chamber maintained at $14 \mathrm{~h}$ of light and $10 \mathrm{~h}$ of darkness with day and night temperatures of 21 and $18^{\circ} \mathrm{C}$, respectively. Plants were rated 18 days after inoculation for root rot severity. The experimental design was an RCB with three replications. The experiment was repeated once.

Paper towel method. A paper towel method described earlier by Mitchell et al. (11) for studying population dynamics of Aphanomyces euteiches in soil was used to evaluate the response of dry bean geno- types to $F$. solani $\mathrm{f}$. sp. phaseoli. In 266-ml plastic drinking cups with holes at the base for drainage, two seeds of a genotype were placed in premium grade coarse dry vermiculite. Cups were then placed in a growth chamber maintained at $14 \mathrm{~h}$ of light and $10 \mathrm{~h}$ of darkness with day and night temperatures of 21 and $18^{\circ} \mathrm{C}$, respectively. Plants were allowed to grow and were watered regularly. In a 2-liter conical flask, 1 liter of wheat grain was soaked in distilled water for $24 \mathrm{~h}$. Excess water was decanted, and the grain was sterilized at $121^{\circ} \mathrm{C}$ for $20 \mathrm{~min}$ and allowed to cool completely. Two petri plates containing a sporulating culture of $F$. solani f. sp. phaseoli on HSPDA were divided into smaller units and placed in the flask under sterile conditions. The flask was kept at room temperature for 7 days, and was periodically shaken to allow the fungus to grow throughout the contents of the flask. Ten-day-old bean seedlings were carefully removed from the cups and their roots were gently washed to remove the vermiculite. The roots of two seedlings were placed on a layer of four bleached paper towels. The $F$. solani f. sp. phaseoliinfested wheat grains (5 g) were evenly sprinkled on the roots. The paper towel layer was wrapped and moistened with distilled water. Three such wraps were placed in a plastic bag. The bags were allowed to stand on an aluminum stand and placed in the growth chamber. Ten days after inoculation, plants were removed, washed carefully, and rated for root rot severity. The experiment was designed as an RCB with three replications and repeated once.

Perham and Park Rapids field trials. Field trials were established in 2005 at Perham and Park Rapids, MN to evaluate the response of the 11 dry bean genotypes to Fusarium root rot under natural disease pressure. The two field sites have a history of Fusarium root rot and have been used previously as Fusarium root rot disease nurseries by the North Dakota State University dry edible bean breeding program. Corn (Zea mays L.) was grown at both locations in the previous growing season. Both locations were planted on 1 June 2005; the genotypes Montcalm, Red Hawk, VAX 3, Othello, Maverick, and Matterhorn were seeded at a density of 17 seeds $/ \mathrm{m}^{2}$, and Eclipse, T-39, Norstar, Vista, and Rojo Chiquito were seeded at a density of 22 seeds $/ \mathrm{m}^{2}$. Plots were four rows wide on $76-\mathrm{cm}$ centers and $6.1 \mathrm{~m}$ long; plots were later trimmed to $4.6 \mathrm{~m}$ long. The statistical design was an RCB with three replications. Both locations were maintained using standard regional agronomic practices for dry edible bean production, which included fertilizer and herbicide applications. Ten consecutive plants from an outside row were dug and taken to the laboratory, where they were washed with water and assessed for root rot sever- ity on 10 August, 70 days after planting (DAP). The two center rows of every plot were harvested on 19 September using a small plot combine. After harvest, seed were dried under heated forced air $\left(32^{\circ} \mathrm{C}\right)$ in a grain dryer for $48 \mathrm{~h}$, and yield was calculated to kilograms per hectare.

Fargo field trial. A field trial consisting of small hill plots was established 9 June 2005 at Fargo, ND to evaluate the response of the 11 dry bean genotypes to Fusarium root rot. Soybean (Glycine max (L.) Merr.) was the previous crop grown at the Fargo site. Although the soil at Fargo was naturally infested with $F$. solani f. sp. phaseoli, plots were augmented with $F$. solani $\mathrm{f}$. sp. phaseoli-infested wheat grain which was prepared the same way as in the paper towel method described earlier. The $F$. solani f. sp. phaseoli-infested wheat grain was dried at $32.2^{\circ} \mathrm{C}$ for $48 \mathrm{~h}$, then ground into a coarse mixture at $18,000 \mathrm{rpm}$ for 5 min using a commercial blender (Waring Products, Inc., Torrington, CT). Holes, 15 $\mathrm{cm}$ diameter wide and $15 \mathrm{~cm}$ deep, were made in the field with a post-hole digger, and $100 \mathrm{ml}$ of $F$. solani f. sp. phaseoliinfested wheat grain inoculum was placed in the hole. The inoculum was covered with soil, and 10 seeds of a genotype were planted $4 \mathrm{~cm}$ deep in the soil layer above the inoculum. Plots were spaced $30 \mathrm{~cm}$ apart. All emerged plants were dug on 12 August (64 DAP) and were taken back to the laboratory for root and disease analysis. Roots were carefully washed and root rot severity was assessed. Roots in Fargo were evaluated 64 DAP compared with 70 DAP for Perham and Park Rapids but plant development was not noticeably different at Fargo compared with the other locations, and this 6-day difference did not likely play a role in differences in disease development at the locations. The experimental design was an RCB with four replications.

Statistical analyses. Data were analyzed using the general linear model procedure (PROC GLM) of SAS (SAS Institute Inc., Cary, NC). Means were compared using Fisher's protected least significant difference (LSD), where $\alpha=$ 0.05 . Relationships of the variables among the different trials were evaluated using Pearson correlation analysis (PROC CORR) in SAS.

\section{RESULTS}

Growth-chamber trials. Significant $(P$ $\leq 0.05$ ) differences in root rot severity among dry bean genotypes occurred with the sand-cornmeal inoculum layer method, spore suspension method, and paper towel method (Table 2). VAX 3 had the lowest root rot severity rating of all the genotypes tested in each method, and Rojo Chiquito had the highest root rot severity rating in each method.

Field trials. At the Perham field trial, significant $(P \leq 0.05)$ differences among 
genotypes occurred for root rot severity and yield (Table 3). VAX 3 had the lowest root rot severity rating of all the genotypes tested and Othello and Montcalm had the highest root rot severity ratings. VAX 3 had the greatest yield of all the genotypes except Othello and Eclipse.

At the Park Rapids field trial, significant $(P \leq 0.05)$ differences among genotypes occurred for root rot severity and yield (Table 3). Eclipse, VAX 3, and T-39 had the lowest root rot severity ratings of all the genotypes tested and Matterhorn had the highest root rot severity rating. VAX 3 , Othello, Eclipse, and Maverick had the greatest yields of all the genotypes tested.

At the Fargo field trial, Norstar and T-39 did not emerge in any of the plots; therefore, root rot severity was not measured on these genotypes at this location. Significant $(P \leq 0.05)$ differences among genotypes occurred for root rot severity (Table 3 ). VAX 3 had the lowest root rot severity rating of all the genotypes tested and Red Hawk had the highest root rot severity rating but was not significantly different than Rojo Chiquito and Othello.

Correlations. Several significant $(P \leq$ $0.05)$ correlations among tested variables were detected (Table 4). Root rot severity values from the sand-cornmeal inoculum layer, spore suspension, and paper towel methods were positively correlated with root rot severity values from the Perham and Fargo field trials. The sand-cornmeal inoculum layer, spore suspension, and paper towel methods were all positively correlated with each other as well. The root rot severity values from the Perham field trial were positively correlated with the root rot severity values from the Park Rapids and the Fargo field trials. Yield from the Perham field trial was positively correlated with yield from the Park Rapids field trial.

\section{DISCUSSION}

Of all the genotypes tested, VAX 3 consistently had low root rot severity ratings in all of the trials. Because VAX 3 also has resistance to common bacterial blight (Xanthomonas campestris pv. phaseoli; 14), which is a common disease in North Dakota and Minnesota, this genotype would be useful for development of cultivars adapted to this region. VAX 3 generally would be too late-maturing for this region (14) but has good yield potential because it was also among the best for yield in the field trials. Because VAX 3 has resistance to both $F$. solani f. sp. phaseoli and common bacterial blight, this line would be very useful as a source of multiple resistance as well as improved seed yield and plant structure for kidney bean improvement. Red kidney bean has likely suffered the most losses due to $F$. solani $\mathrm{f}$. sp. phaseoli in North Dakota and Minnesota. Previous attempts to introduce $F$. solani f. sp. phaseoli resistance into red kidney bean have been difficult due to the market's emphasis on certain quality traits in red kidney bean. The genotype T-39 also showed a good level of resistance to $F$. solani f. sp. phaseoli in the field and growth-chamber trials. Schneider and Kelly (13) reported that T-39 had one of the lowest Fusarium root rot ratings of several genotypes tested in greenhouse and field trials in Michigan, which means that the resistance present in T-39 may be effective against different isolates of $F$. solani f. sp. phaseoli in different regional environments.

All three methods used in our trials to evaluate the response of dry bean genotypes to Fusarium root rot in the growth chamber were effective in finding differences in susceptibility among the genotypes. Root rot reactions obtained from each growth-chamber screening method were significantly $(P \leq 0.05)$, highly correlated with root rot reactions obtained from the Perham and Fargo field trials but not the Park Rapids field trial. The level of Fusarium root rot pressure at the Park Rapids field trial was lower than the other

Table 2. Fusarium root rot severity ratings of 11 dry bean genotypes using sand-cornmeal inoculum layer, spore suspension, and paper towel methods in the growth chamber ${ }^{\mathrm{a}}$

\begin{tabular}{lccc}
\hline Genotype & $\begin{array}{c}\text { Sand-cornmeal } \\
\text { inoculum layer method }\end{array}$ & $\begin{array}{c}\text { Spore suspension } \\
\text { method }\end{array}$ & $\begin{array}{c}\text { Paper towel } \\
\text { method }\end{array}$ \\
\hline Rojo Chiquito & 4.2 & 4.3 & 4.6 \\
Vista & 3.9 & 3.5 & 3.7 \\
Othello & 3.4 & 3.4 & 3.6 \\
Matterhorn & 3.3 & 3.0 & 3.3 \\
Montcalm & 3.1 & 3.5 & 3.5 \\
Norstar & 3.1 & 3.5 & 3.4 \\
Red Hawk & 2.9 & 3.2 & 3.2 \\
Maverick & 2.3 & 2.6 & 2.6 \\
Eclipse & 1.7 & 1.7 & 1.7 \\
T-39 & 1.6 & 1.4 & 1.5 \\
VAX 3 & 1.3 & 1.2 & 1.3 \\
LSD & 0.3 & 0.2 & 0.2 \\
CV $(\%)^{\mathrm{c}}$ & 18.0 & 16.6 & 12.5 \\
\hline
\end{tabular}

a Data represent means from two trials combined for analysis; means reported are Fusarium root rot severity ratings based on a 1-to-7 scale.

${ }^{\mathrm{b}}$ Fisher's protected least significant difference $(\alpha=0.05)$.

${ }^{c}$ Coefficient of variation.

field trials, which may be the reason why correlations between this trial and the growth-chamber screening methods were not significant. The reason for the reduced root rot pressure at the Park Rapids location is unknown. The soil at the Perham location is very coarse, loamy sand over a gravel base with low organic matter ( 2 to $3 \%$ ), whereas the soil at Park Rapids has more organic matter (4.5 to $5.5 \%$ ) (K. F. Grafton, personal observation). The soil type at Perham is typical of the sandy soils in central Minnesota that have a welldeveloped Bt horizon with increased bulk density and soil strength and reduced hydraulic conductivity which can exacerbate root rot (8). In addition, the Perham area has had a longer history of dry bean production and may have a higher population density of $F$. solani $\mathrm{f}$. sp. phaseoli in that soil. Differences in F. solani f. sp. phaseoli population densities at the two locations

Table 3. Fusarium root rot severity ratings and yield of different dry bean genotypes at Perham, MN, Park Rapids, MN, and Fargo, ND in 2005

\begin{tabular}{|c|c|c|}
\hline Location, genotype $^{a}$ & $\begin{array}{c}\text { Severity } \\
(1-7)\end{array}$ & $\underset{(\mathrm{kg} / \mathrm{ha})^{\mathbf{b}}}{\text { Yield }}$ \\
\hline \multicolumn{3}{|l|}{ Perham, MN } \\
\hline Othello & 5.0 & 2,705 \\
\hline Montcalm & 4.9 & 1,570 \\
\hline Rojo Chiquito & 4.7 & 2,208 \\
\hline Vista & 4.5 & 2,242 \\
\hline Red Hawk & 4.6 & 1,711 \\
\hline Matterhorn & 3.4 & 1,888 \\
\hline Norstar & 3.4 & 1,756 \\
\hline Maverick & 3.3 & 2,486 \\
\hline Eclipse & 2.4 & 2,705 \\
\hline T-39 & 2.0 & 2,446 \\
\hline VAX 3 & 1.3 & 3,122 \\
\hline LSD & 0.2 & 571 \\
\hline $\mathrm{CV}(\%)$ & 3.0 & 14.8 \\
\hline \multicolumn{3}{|l|}{ Park Rapids, MN } \\
\hline Matterhorn & 3.7 & 2,184 \\
\hline Montcalm & 3.4 & 1,941 \\
\hline Red Hawk & 3.0 & 1,915 \\
\hline Othello & 2.6 & 3,030 \\
\hline Vista & 2.3 & 2,375 \\
\hline Rojo Chiquito & 2.1 & 2,220 \\
\hline Maverick & 2.0 & 2,941 \\
\hline Norstar & 1.7 & 2,307 \\
\hline Eclipse & 1.3 & 2,961 \\
\hline VAX 3 & 1.3 & 3,236 \\
\hline T-39 & 1.2 & 2,409 \\
\hline LSD & 0.2 & 482 \\
\hline $\mathrm{CV}(\%)$ & 4.2 & 11.3 \\
\hline \multicolumn{3}{|l|}{ Fargo, ND } \\
\hline Red Hawk & 4.7 & ND \\
\hline Rojo Chiquito & 4.3 & ND \\
\hline Othello & 4.2 & ND \\
\hline Montcalm & 4.0 & ND \\
\hline Matterhorn & 3.5 & ND \\
\hline Maverick & 3.2 & ND \\
\hline Vista & 2.7 & ND \\
\hline Eclipse & 2.4 & ND \\
\hline VAX 3 & 1.5 & ND \\
\hline LSD & 0.7 & ND \\
\hline $\mathrm{CV}(\%)$ & 12.0 & ND \\
\hline
\end{tabular}

${ }^{a}$ LSD $=$ Fisher's protected least significant difference $(\alpha=0.05)$ for an individual location and $\mathrm{CV}=$ coefficient of variation for an individual location.

${ }^{\mathrm{b}} \mathrm{ND}=$ yield was not determined at the Fargo, ND location. 
Table 4. Pearson correlation coefficients (CCs) between Fusarium root rot ratings, bean root lengths, and bean yields from growth-chamber trials and field trials at Perham, MN, Park Rapids, MN, and Fargo, ND in 2005

\begin{tabular}{llcc}
\hline Variables $^{\mathbf{a}}$ & & CCs & Probability \\
\hline SCILM & PMRR & 0.88 & 0.0004 \\
SCILM & PRRR & 0.59 & 0.0544 \\
SCILM & FRR & 0.67 & 0.0492 \\
SSM & PMRR & 0.90 & 0.0001 \\
SSM & PRRR & 0.58 & 0.0636 \\
SSM & FRR & 0.79 & 0.0110 \\
PTM & PMRR & 0.89 & 0.0002 \\
PTM & PRRR & 0.58 & 0.0616 \\
PTM & FRR & 0.76 & 0.0171 \\
SCILM & SSM & 0.96 & 0.0001 \\
SCILM & PTM & 0.98 & 0.0001 \\
SSM & PTM & 0.99 & 0.0001 \\
PMRR & PRRR & 0.67 & 0.0240 \\
PMRR & FRR & 0.86 & 0.0028 \\
PRRR & FRR & 0.62 & 0.0752 \\
PMRR & PMY & -0.57 & 0.0679 \\
PRRR & PRY & -0.60 & 0.0506 \\
PMY & PRY & 0.93 & 0.0001 \\
\hline
\end{tabular}

a FRR = Fargo root rot, PMRR = Perham root rot, $\mathrm{PMY}=$ Perham yield, PRRR = Park Rapids root rot, $\mathrm{PRY}=$ Park Rapids yield, PTM = paper towel method, SCILM = sand-cornmeal inoculum layer method, and $\mathrm{SSM}=$ spore suspension method.

could result in different results; Wang et al. (16) reported that different responses to treatments occurred at two similar Minnesota field sites when working with dry bean, and attributed the different reactions at the two locations to different soil population densities of $F$. oxysporum at the two sites.

Because all three growth-chamber screening methods positively and significantly correlated with two of the field trials, any of these methods could potentially be used to identify new sources of resistance to Fusarium root rot. The spore sus- pension method used in our trials was based on a spore suspension method developed by Schneider and Kelly (13), in which they reported that this method significantly correlated with field trials and recommended that it could be used to effectively screen for resistance to $F$. solani f. sp. phaseoli. Chaudhary et al. (7) reported that this spore suspension method did not give as high reproducibility among experiments as an inoculum layer method which utilized $F$. solani f. sp. phaseoliinfested PDA discs placed in a layer in the soil below the seed. The inoculum layer method described by Chaudhary et al. (7) is similar to our sand-cornmeal inoculum layer method. From our research, any of the growth-chamber screening methods tested would be ideal for large-scale screenings of germplasm, because they are efficient, reliable, and relatively inexpensive.

\section{ACKNOWLEDGMENTS}

This project was funded by grants from the Northarvest Bean Growers Association and the North Dakota State Board of Agriculture Research and Education (SBARE). The authors thank C. Chesrown, R. Miller, G. Rojas-Cifuentes, J. VanderWal, and $\mathrm{K}$. Wise for assisting with the field trials.

\section{LITERATURE CITED}

1. Beebe, S. E., Bliss, F. A., and Schwartz, H. F. 1981. Root rot resistance in common bean germ plasm of Latin American origin. Plant Dis. 65:485-489.

2. Bilgi, V. N. 2006. Response of common bean genotypes to Fusarium root rot under field and controlled conditions. Master's thesis, North Dakota State University, Fargo.

3. Boomstra, A. G., Bliss, F. A., and Beebe, S. E. 1977. New sources of Fusarium root rot resistance in Phaseolus vulgaris L. J. Am. Soc. Hortic. Sci. 102:182-185.

4. Bradley, C. A., and Luecke, J. L. 2004. 2002 Dry bean grower survey. N. D. State Univ. Ext. Rep. No. PP-1265.
5. Bravo, A., Wallace, D. H., and Wilkinson, R E. 1969. Inheritance of resistance to Fusarium root rot of beans. Phytopathology 59:19301933.

6. Burke, D. W., and Miller, D. E. 1983. Control of Fusarium root rot with resistant beans and cultural management. Plant Dis. 67:13121317.

7. Chaudhary, S., Anderson, T. R., Park, S. J., and $\mathrm{Yu}, \mathrm{K}$. 2006. Comparison of screening methods for resistance to Fusarium root rot in common beans (Phaseolus vulgaris L.). J. Phytopathol. 154:303-308.

8. Estevez de Jensen, C., Kurle, J. E., and Percich, J. A. 2004. Integrated management of edaphic and biotic factors limiting yield of irrigated soybean and dry bean in Minnesota. Field Crops Res. 86:211-224.

9. Hassan, A. A., Wallace, D. H., and Wilkinson, R. E. 1971. Genetics and heritability of resistance to Fusarium solani f. sp. phaseoli in beans. J. Am. Soc. Hortic. Sci. 96:623-627.

10. Knodel, J. J., Bradley, C. A., Luecke, J. L., and Mars, G. A. 2007. 2004 and 2005 Dry bean grower survey. N. D. State Univ. Ext. Rep. No. PP-1265.

11. Mitchell, J. E., Bhalla, H. S., and Yang, G. H. 1969. An approach to the study of the population dynamics of Aphanomyces euteiches in soil. Phytopathology 59:206-212.

12. Mondal, S. N., Kageyama, K., and Hyakumachi, M. 1996. Chlamydospore formation in Fusarium solani f. sp. phaseoli in root extracts of crop plants and their virulence to kidney beans (Phaseolus vulgaris L.). Soil Biol. Biochem. 28:539-543.

13. Schneider, K. A., and Kelly, J. D. 2000. A greenhouse screening protocol for Fusarium root rot in bean. HortScience 35:1095-1098.

14. Singh, S. P., Munoz, C. G., and Teran, H. 2001. Registration of common bacterial blight resistant dry bean germplasm VAX 1, VAX 3, and VAX 4. Crop Sci. 41:275-276.

15. Strausbaugh, C. A., Bradley, C. A., Koehn, A C., and Forster, R. L. 2004. Survey of root diseases of wheat and barley in southeastern Idaho. Can. J. Plant Pathol. 26:167-176.

16. Wang, D., Kurle, J. E., Estevez de Jensen, C. and Percich, J. A. 2004. Radiometric assessment of tillage and seed treatment effect on soybean root rot caused by Fusarium spp. in central Minnesota. Plant Soil 258:319-331. 